\title{
Impact of climatic variability of the temperature- humidity index during winter, spring and summer seasons in Egypt on the growth of the native bovine calves
}

\section{Research Article}

Keywords:

Posted Date: November 4th, 2022

DOI: https://doi.org/10.21203/rs.3.rs-1308671/v2

License: (1) This work is licensed under a Creative Commons Attribution 4.0 International License.

Read Full License 


\section{Abstract}

The full text of this preprint has been withdrawn by the authors due to author disagreement with the posting of the preprint. Therefore, the authors do not wish this work to be cited as a reference. Questions should be directed to the corresponding author.

\section{Full Text}

The authors have withdrawn this preprint from Research Square. 